\title{
Quantifying water productivity using seed priming and micro irrigation in wheat (Triticum aestivum)
}

\author{
Raj Pal Meena*, Ramesh Kumar Sharma, R Sendhil, Subhash Chander Tripathi and Subhash \\ Chander
}

ICAR-Indian Institute of Wheat and Barley Research, Karnal, India

\section{Article history}

Received: 07 December 2017

Revised : 15 January 2018

Accepted: 12 February2018

\section{Citation}

Meena RP, RK Sharma, R Sendhil, SC Tripathi and S Chander. 2018. Quantifying water productivity using seed priming and micro irrigation in wheat (Triticum aestivum). Wheat and Barley Research 10(1): .20-24. doi.org/10.25174/2249-4065/ $2018 / 69924$

\section{*Corresponding author \\ Email: adityarajjaipur@gmail.com}

(C) Society for Advancement of Wheat and Barley Research

\begin{abstract}
Field studies were conducted during the four rabi seasons (2011-12 to 2014-15) to investigate the impact of seed priming and micro irrigation on crop establishment, growth, productivity, and water productivity in wheat under different moisture regimes. Results indicated that sprouted seed $\left(5830 \mathrm{~kg} \mathrm{ha}^{-1}\right)$ and primed seed $\left(5766 \mathrm{~kg} \mathrm{ha}^{-1}\right)$ produced significantly higher grain yield in comparison to un-primed seeds (5416 $\left.\mathrm{kg} \mathrm{ha}^{-1}\right)$. The germination was quick in the primed and sprouted seeds relative to non-primed seeds resulting in a better crop establishment and higher yield under optimum, sub-optimum and dry soil conditions. Irrigation method treatments viz., check basin, drip, sprinkler and drip + rainport showed that the grain yield was highest in the drip + rainport. Water productivity was highest in drip method of irrigation $\left(1.61 \mathrm{~kg} \mathrm{~m}^{-3}\right)$ followed by drip + rainport method $\left(1.60 \mathrm{~kg} \mathrm{~m}^{-3}\right)$ with a maximum mean productivity of $5539 \mathrm{~kg} \mathrm{ha}^{-1}$. Around $600 \mathrm{~m}^{3} \mathrm{ha}^{-1}$ has been saved using seed priming thus reducing the cultivation cost by Rs. 382/ha. Among the micro irrigation techniques, water saved was highest in drip followed by sprinkler and drip + rainport. The study suggests for adoption of drip and seed priming to take advantage of yield enhancement as well as cost reduction through reduced utilisation of water.
\end{abstract}

Key words: Micro irrigation; seed priming; water productivity; wheat yield

\section{Introduction}

Ensuring food security through irrigated agriculture is widely advocated by researchers since it influences the crop yield significantly. However, improving the efficiency and productivity of water in agriculture is a daunting task on sustainability front. In the era of precision agriculture, it becomes an utmost priority to use the water rationally as the utilization over years has been alarming particularly in the Indo-Gangetic Plains (IGP). The depleting water resources endanger the future need of irrigation water as well as sustainable food production. It is estimated that water needed for wheat in India hovers around 1500 litres per $\mathrm{kg}$ of grain production (FAO, 2012). In India around 97 per cent of the crop area is grown under irrigated condition and consumes approximately 127,671 million $\mathrm{m}^{3}(16 \%$ of global water footprint in wheat) per annum. Among the precision water saving technologies, seed priming and micro irrigation technologies registered better efficiency and productivity coupled with supplementary benefits (Meena et al., 2015; Mondal and Bose, 2014; Shabbir et al., 2014; Meena et al., 2013; Rajpar et al., 2006; Clark et al., 2001, Harris and Hollington, 2001; Harris et al., 1999; Harris, 1996). In the milieu, the present study was proposed to investigate the effect of seed priming (matriconditioning) and micro irrigation on wheat yield and to quantify the water savings from these techniques. 


\section{Material and methods}

Precision field experiments on seed priming and micro irrigation using split plot design and randomized block design respectively were conducted at the ICARIndian Institute of Wheat and Barley Research, Karnal (2943'N, 76 ${ }^{\circ} 58^{\prime} \mathrm{E}$ and $245 \mathrm{~m}$ AMSL), located at Karnal, Haryana. The average annual rainfall of Karnal is 744 $\mathrm{mm}$, of which about 80 percent is received during the monsoon. The mean minimum temperature ranged between $6-7^{\circ} \mathrm{C}$ in winter. The experiments were conducted for four consecutive Rabi seasons from 201112 to 2014-15. Under seed priming, three main plot treatments viz., seeding at optimum moisture, seeding at sub-optimal moisture and seeding in dry soil; and three sub plot treatments viz., no seed priming, seed priming and sprouted seed were carried out. Seed priming was planned in wheat since the process advances the crop sowing by about 10-15 days by avoiding the pre-sowing irrigation. The fortnight duration is very crucial in rice-wheat cropping system as the planting of wheat usually gets delayed under this system due to late harvesting of rice which can cause yield penalty. Further, there will be poor establishment of wheat due to lack of optimum soil moisture. Seed priming was carried out in gunny bags (Basra et al., 2003). For seed priming, soaked seeds were placed overnight in gunny bags and thereafter spread between two gunny bags. The gunny bags were kept under moist condition for the whole treatment period i.e. 12 hours. For sprouting treatment, the seeds were soaked in fresh water for 10 hours and then spread between two wet gunny bags for 14 hours. The experiment on irrigation consisted of four treatments (micro irrigation - drip, sprinkler and drip + rainport techniques - against check basin irrigation). The drip+rainport combo treatment was carried out to mitigate the terminal heat stress, a serious issue in wheat that hamper the crop productivity. For this water was sprinkled for 15 minutes by sprinkler system whenever the day temperature crosses $30^{\circ} \mathrm{C}$ at noon to mitigate the heat stress. All recommended package of practices except irrigation and fertilizer application, were followed. Further, the physical water productivity was estimated (Abdullaev et al., 2007). Water productivity in $\mathrm{kg} \mathrm{m}^{-}{ }^{3}$ is the ratio of wheat output in $\mathrm{kg} \mathrm{ha}^{-1}$ to the estimated water footprint in $\mathrm{m}^{3} \mathrm{ha}^{-1}$. The total water footprint was estimated by multiplying the total hours of irrigation during a season with the volume of water extracted per hour apart from the amount of rainfall received.
Based on this, the average discharge of tube well of 10 $\mathrm{HP}$ was estimated as $600 \mathrm{~m}^{3} \mathrm{ha}^{-1}$ per irrigation (Kaur et al., 2012). SAS (Statistical Analysis System) version 10.3 was used to analyze the recorded observations.

\section{Results and discussion}

Experiments on seed priming and seeding methods revealed significant effect of seed priming treatments but seeding method had non significant effect. The highest yield was obtained in sowing of sprouted seeds (5831 kg ha- ${ }^{1}$ ) followed by sowing of primed seeds $\left(5767 \mathrm{~kg} \mathrm{ha}{ }^{-1}\right)$. Both these treatments were significantly better than the no priming treatment(Table 1). The yield gain is attributed to better germination, crop stand and establishment corroborating the earlier research findings (Harris et al., 2001; Rashid et al., 2002; Musa et al., 1999).

The results of experiment on micro irrigation revealed that the maximum yield was recorded in drip+rainport treatment $\left(5539 \mathrm{~kg} \mathrm{ha}^{-1}\right)$ with a water use efficiency of $1.60 \mathrm{~kg} \cdot \mathrm{m}^{-3}$, followed by check basin method $(5301 \mathrm{~kg}$ $\left.\mathrm{ha}^{-1}\right)$ but with the minimum water productivity of 1.22 $\mathrm{kg} \cdot \mathrm{m}^{-3}$ (Table 1). Drip irrigation produced $5205 \mathrm{~kg} \mathrm{ha}^{-1}$ with the water use efficiency of $1.61 \mathrm{~kg} \cdot \mathrm{m}^{-3}$ and sprinkler irrigation registered $5194 \mathrm{~kg} \mathrm{ha}^{-1}$ with the water use efficiency of $1.58 \mathrm{~kg} \cdot \mathrm{m}^{-3}$. Water footprints comprising fresh water irrigation and rainfall indicated that seed priming consumed less water in comparison to unpriming (Table 1 and 2) with seeding at sub-optimal soil moisture level registering the lowest footprint (Table 1). Similarly, under micro irrigation systems, drip technique resulted in less water footprint in comparison to others. The water productivity per hectare was highest in the case of sprouted seed technique coupled with seeding in sub-optimal soil moisture level (M3S2).

Overall, the water productivity was found to be more under micro irrigation system (drip and sprinkler irrigation) and relatively efficient in comparison to surface irrigation method (full irrigation approach). Further, it helped to save around 31\% of water apart from labour saving and drudgery reduction. Stress for water is the possible reason for the low yield obtained in surface irrigation methods as the number of irrigations is low in this case relative to micro irrigation. Further, large irrigation interval after January coinciding with the stem elongation stage might lead to reduction in the number of productive tillers per unit area. Insufficient irrigation water applied in March during the heading 
and flowering stage, which coincides with high evapotranspiration, adversely affected the grain formation. The results corroborate the findings of Zhang and Oweis (1999) that the crop sensitivity to water stress occurs from zadoks scale 30 to 39 (stem elongation or jointing stage) to zadoks scale 41 to 49 (booting stage), followed by zadoks scale 61 to 69 (flowering or anthesis) stage. Water use efficiency has increased chiefly due to less amount of water footprint recorded under micro-irrigation systems (16-33\% less) over surface irrigation. The level of water footprint saved in physical and monetary terms indicated that around $600 \mathrm{~m}^{3} \mathrm{ha}-{ }^{1}$ has been saved using seed priming which reduced the irrigation cost (Table 2).

Table 1. Effect of seed priming at different moisture levels on yield of wheat (Pooled data of 4 years)

\begin{tabular}{lc}
\hline Treatments & $\begin{array}{c}\text { Grain yield } \\
\left(\mathrm{kg} \mathrm{ha}^{-1}\right)\end{array}$ \\
\hline A. Seeding Method & \\
\hline $\mathrm{M}_{1}:$ Seeding at optimum moisture & 5723 \\
$\mathrm{M}_{2}$ : Seeding at sub-optimal soil moisture & 5637 \\
$\mathrm{M}_{3}$ : Seeding in dry soil followed by irrigation & 5652 \\
$\mathrm{CD}(5 \%)$ & $\mathrm{NS}$ \\
\hline $\mathrm{B}$. Seed Priming & \\
\hline $\mathrm{S}_{1}:$ No seed priming & 5416 \\
$\mathrm{~S}_{2}:$ Seed priming & 5767 \\
$\mathrm{~S}_{3}:$ Sprouted seeds & 5831 \\
$\mathrm{CD}(5 \%)$ & 206 \\
\hline
\end{tabular}

Table 2. Effect of seed priming at different moisture levels on yield and water use efficiency of wheat (Pooled data of 4 years)

\begin{tabular}{lccc}
\hline Treatment & $\begin{array}{c}\text { Grain yield } \\
\text { in kg ha }\end{array}$ & $\begin{array}{c}\text { Grain yield } \\
\text { in kg ha }\end{array}$ & $\begin{array}{c}\text { Water use } \\
\text { efficiency }\left(\mathrm{kg} \cdot \mathrm{m}^{-3}\right)\end{array}$ \\
\hline $\mathrm{M}_{1} \mathrm{~S}_{1}$ & 5460 & 4650 & 1.19 \\
$\mathrm{M}_{1} \mathrm{~S}_{2}$ & 5749 & 4650 & 1.26 \\
$\mathrm{M}_{1} \mathrm{~S}_{3}$ & 5962 & 4650 & 1.31 \\
$\mathrm{M}_{2} \mathrm{~S}_{1}$ & 5404 & 4275 & 1.29 \\
$\mathrm{M}_{2} \mathrm{~S}_{2}$ & 5713 & 4275 & 1.37 \\
$\mathrm{M}_{2} \mathrm{~S}_{3}$ & 5792 & 4275 & 1.39 \\
$\mathrm{M}_{3} \mathrm{~S}_{1}$ & 5383 & 4275 & 1.29 \\
$\mathrm{M}_{3} \mathrm{~S}_{2}$ & 5837 & 4275 & 1.41 \\
$\mathrm{M}_{3} \mathrm{~S}_{3}$ & 5736 & 4275 & 1.38 \\
$\mathrm{CD}_{2}(5 \%)$ & 175 & & \\
\hline
\end{tabular}

Where, $\mathrm{M}_{1}$, Seeding at optimum moisture level; $\mathrm{M}_{2}$, seeding at sub-optimal soil moisture level; $M_{3}$, seeding in dry soil followed by irrigation and $S_{1}$, no seed priming; $\mathrm{S}_{2}$, seed priming; $\mathrm{S}_{3}$, sprouted seeds
Cost reduction comprises the savings in cost of irrigated water, labour cost as well as charges on electricity. The cost of irrigation was lowest in treatment where seeding was done under sub-optimal moisture level since one irrigation has been foregone $\left(600 \mathrm{~m}^{3} \mathrm{ha}^{-}\right)$relative to the conventional practice. Among the micro irrigation techniques, water footprint saved was highest in drip followed by sprinkler and drip+rainport. The cost remained low in comparison to surface method of irrigation (check basin) due to less water and labour requirement. The net savings under micro irrigation was higher for drip and sprinkler, followed by drip+rainport (Fig 1).

On the basis of four years study, it is concluded that primed and sprouted seeds may be practiced to enhance the crop establishment, growth and yield of wheat under moisture stress conditions. Poor establishment of crop due to delayed sowing and lack of optimum soil moisture is a major constraint in areas where intensive cropping systems are in practice. Further, priming and sprouted seeds are simple to adopt and cost effective. Proper crop establishment increase the competitiveness against weeds and tolerance to other abiotic stress (Clark et al., 2001). In addition, this technique helps in advancing the wheat sowing by about 10-15 days as well as avoiding the pre-sowing irrigation. Under ricewheat system, this technique is highly recommended for utilizing the residual soil moisture after rice harvest, saving crop duration time, sacrificing one irrigation along with yield enhancement followed by other supplementary agronomic and economic benefits. Similarly, proper water management through micro irrigation helps the crop in quick utilization of the available nutrients resulting in higher growth and yield of wheat as compared to surface method of irrigation. Micro irrigation increases the yield potential by producing a congenial environment resulting in higher assimilation of plant nutrients apart from increasing the root absorption capacity (Hao et al., 2008). The technique facilitates to sacrifice the water footprint by $31 \%$ which is made possible through maintaining the available soil moisture at low water tension throughout growth period (Patel et al., 2006). Further, it supply water to the crop matching its evapo-transpiration demand and provide optimum soil moisture at critical growth stages resulting in improved water use efficiency (Kipkorir et al., 2002).

Altogether, the study recommends the micro irrigation systems coupled with seed priming practise for higher wheat and water productivity. 


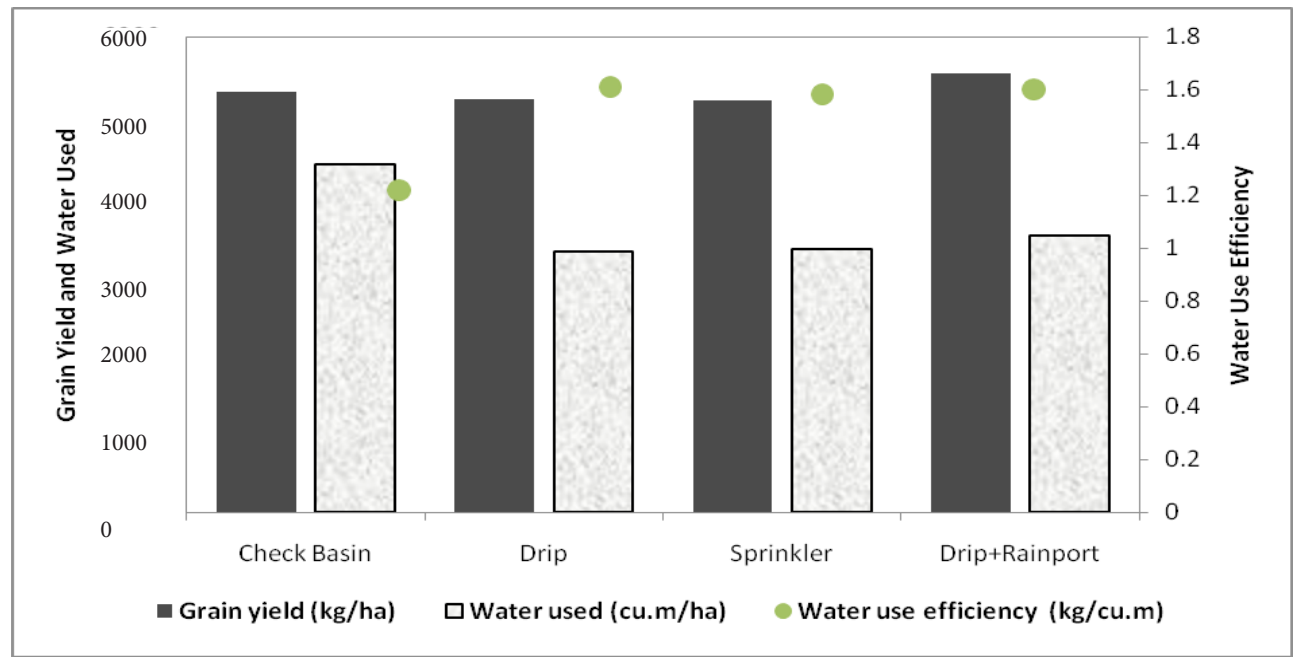

Fig. 1 Effect of micro irrigation on wheat yield, water used and productivity

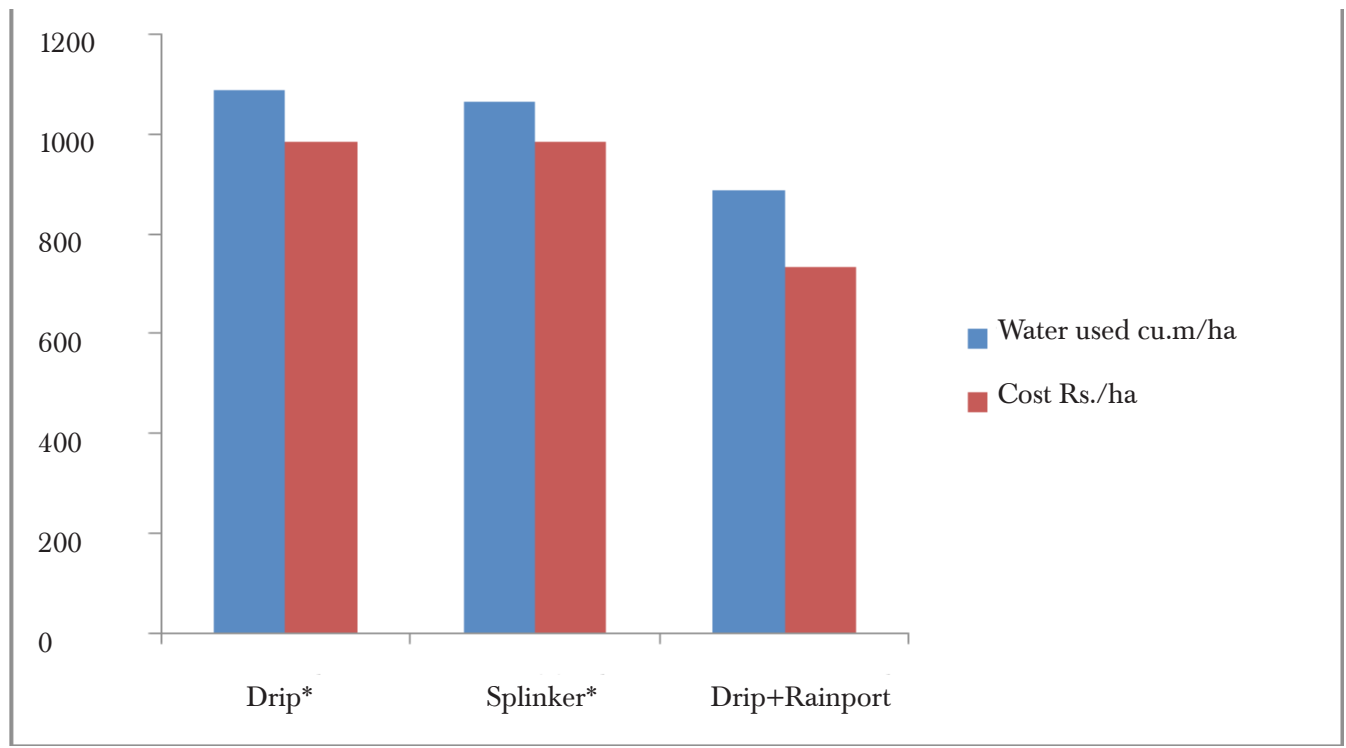

Fig. 2 Water savings and cost of water savings under different techniques against conventional practices

\section{Acknowledgement}

The authors are grateful for the support from the Director, ICAR-IIWBR, , Karnal and Jain Irrigations India Limited for providing micro irrigation facility for conducting research in public-private partnership mode.

\section{References}

1. Abdullaev I, MU Husan, and K Jumaboev. 2007. Water saving and economic impacts of land leveling: The case study of cotton production in Tajikistan. Irrigation Drainage System 21: 251-263.
2. Basra SMA, IA Pannu and I Afzal .2003. Evaluation of seedling vigor of hydro and matriprimed wheat (Triticum aestivum L.) seeds. International Journal of Agricultural Biology 5: 121-123.

3. Clark LJ, WR Whalley, J Ellis-Jones, K Dent, HR Rowse, WE Finch-Savage, T Gatsai, L Jasi, NE Kaseke, NE, FS Murungu, CR Riches, and C Chiduza. 2001. On farm seed priming in maize: A physiological evaluation. Eastern and Soutern Africa Regional Maize Conference. pp. 268-273. 
4. Food and Agriculture Organization. 2012. Press Release on World water day 22nd March, 2012.

5. Hao XH, SL Liu, JS Wu, RG Hu, CL Tong and YY Su. 2008. Effect of long-term application of inorganic fertilizer and organic amendments on soil organic matter and microbial biomass in three subtropical paddy soil. Nutrient Cycling in Agroecosystems 81: 17-24.

6. Harris D. 1996. The effects of manure, genotype, seed priming, depth and date of sowing on the emergence and early growth of Sorghum bicolor (L.) Moench in semi-arid Botswana Soil and Tillage Research 40:73-88.

7. Harris D, A Joshi, PA Khan, P Gothkar, and S Sodhi. 1999. On farm seed priming in semi-arid agriculture: development and evaluation in maize, rice and chickpea in India using participatory methods. Experimental Agriculture 35(1): 15-29.

8. Harris D and PA Hollington. 2001. 'On-farm' seed priming-an update. Tropical Agriculture Association (UK) Newsletter 21 (4): 7.

9. Harris D, AK Pathan, P Gothkar, A Joshi, W Chiwasa, and P Nyamudeza. 2001. On-farm seed priming: use participatory methods to revive and refine a key technology. Agricultural System 69(1-2): 151-164.

10. Kaur B, S Singh, BR Garg, JM Singh, and J Singh. 2012. Enhancing water productivity through onfarm resource conservation technology in Punjab agriculture. Agricultural Economics Research Review 25(1): 79-85.

11. Kipkorir EC, D Raes, and B Massawe.2002. Seasonal water production functions and yield response factors for maize and onion in Perkerra, Kenya. Agricultural Water Management 56:229-240.

12. Meena Raj Pal, R Sendhil, SC Tripathi, S Chander, RS Chhokar, and RK Sharma. 2013. Hydro-priming of seed improves the water use efficiency, grain yield and net economic return of wheat under different moisture regimes. SAARC Journal of Agriculture 11(2):149-159.
13. Meena Raj Pal, RK Sharma, RS Chhokar, S Chander, SC Tripathi, R Kumar, and I Sharma. 2015. Improving water use efficiency of rice-wheat cropping system by adopting Micro-Irrigation Systems. International Journal of Bio-resource and Stress Management 6(3):341-345.

14. Mondal S and B Bose. 2014. An impact of seed priming on disease resistance: A review. Microbial Diversity and Biotechnology in food security. pp. 193203.

15. Musa AM, C Johansen, J Kumar and D Harris. 1999. Response of chickpea to seed priming in the High Barind Tract of Bangladesh. International Chickpea and Pigeonpea Newsletter 6: 20-22.

16. Patel RS, PG Patel, JC Patel and MM Patel. 2006. Effect of irrigation and nitrogen on growth and yield of brinjal under drip system. Journal of Maharashtra Agricultural University. 31:173-175.

17. Rajpar I, YM Khanif, and AA Memon. 2006. Effect of Seed Priming on Growth and Yield of Wheat (Triticum aestivum L.) under non-saline conditions. International Journal of Agricultural Research 1(3: 259-264.

18. Rashid A, D Harris, PA Hollington and RA Khattak. 2002. On farm seed priming: a key technology for improving the livelihoods of resource poor-farmers on saline lands. pp. 423-431 in: R. Ahmad and K.A. Malik (eds.) 'Prospects for Saline Agriculture'. Kluwer Academic Publishers, Netherlands.

19. Shabbir I, M Ayub, M Tahir, M Bilal, M Hussain and M Afzal. 2014. Impact of priming techniques on emergence and seedling growth of sesame (Sesamum indicum L.) genotypes Science Asia 1, 92-96.

20. Zhang $\mathrm{H}$ and T Oweis. 1999. Water-yield relations and optimal irrigation scheduling of wheat in the Mediterranean region. Agricultural Water Management 38:195-211. 